\title{
"Does race really matter?" Consumer identity and advertising effectiveness in post-apartheid South Africa
}

\author{
G.D. Johnson* \\ Dauphine Recherches en Management (DRM), UMR CNRS 7088, Université Paris-Dauphine, \\ Place du Maréchal de Lattre de Tassigny, Paris, France \\ guillaume.johnson@gmail.com
}

\begin{abstract}
This study examines the effects of consumers' multiple identities on advertising effectiveness. Based on the Ingroup Bias Theory, the study investigates how the race of an advertisement model, in comparison to another social identity (i.e. socioeconomic position), influences advertising effectiveness. Results indicate that, even though race "matters", the socioeconomic position of the model also predicts advertising effectiveness depending on viewers' racial group. Findings suggest ways to design successful cross-cultural advertising strategies in post-apartheid South Africa.
\end{abstract}

*To whom all correspondence should be addressed.

\section{Introduction}

The demise of the apartheid regime has engendered considerable changes in the targeting practices of the South African advertising industry. While representing the cultural diversity of the country has become a new "corporate responsibility", the emergence of a growing black middle class as a financially viable target has encouraged advertisers to increasingly feature black models in their advertisements (Cassim \& Monteiro, 2001; Milner, 2007; North \& Millard, 2003). Advertisers assume that black viewers will react positively to advertisements featuring black models. However, this assumption may be overly simplistic as other social identities may predict advertising effectiveness (Brumbaugh, 2009; Williams, 1992).

Little South African advertising research has examined the impact of models' race on advertising processing. Extant studies show that the racial group of a model has little to no effect on advertising effectiveness (Orpen, 1975; Grier \& Brumbaugh, 2007; Grier \& Deshpandé, 2001). Yet these studies overlook other social identities such as gender, marital status, and/or socioeconomic position as possible predictors of advertising effectiveness. Understanding the effect of a model's depiction, beyond his/her perceived racial group, is primordial for advertisers to design successful cross-cultural advertising strategies and to reach a growing non-white South African target market which remains highly unknown and misunderstood by marketers. The present study examines how the race of a model, in comparison to another social identity (i.e. socioeconomic position), influences advertising effectiveness.

\section{Model's race and advertising effectiveness}

Studies examining the role of a model's race on advertising effectiveness started in the mid-1960s in the United States (see Cui, 2001). These studies resulted from the emergence of a black middle class and the strategic imperative for marketers to target this segment without alienating white consumers (e.g. Barban \& Cundiff, 1964; Cagley \& Cardozo, 1970; Stafford, Birdwell \& Van Tassel, 1970). The findings of these first studies were equivocal (see Whittler, 1991 for a review). Some of them suggested a positive reaction of white viewers towards advertising featuring black models (Barban \& Cundiff, 1964), whilst some found a neutral reaction (Choudhury \& Schmid, 1974) and others a negative reaction (Cagley \& Cardozo, 1970). These inconsistent results were due to the variety of measures used (see Green, 1999), such as purchase intention (Schlinger \& Plummer, 1972), brand recall (Choudhury \& Schmid, 1974), pupil dilation (Stafford et al., 1970), or sales (Solomon, Bush \& Hair, 1976).

Nevertheless, the overall conclusion was that an advertisement featuring black models generates positive attitude amongst black respondents and not extremely negative attitude amongst white respondents (Whittler, 1991). This comforted advertisers about the use of black models to target black consumers without fearing a negative reaction from white consumers (e.g. Schlinger \& Plummer, 1972; Stafford et al., 1970). However, these studies paid little attention to the underlying psychological processes explaining viewers' reactions to black or white models (Whittler, 1989). Subsequently, the In-group Bias Theory (Brewer, 1979) has been used to provide a sound theoretical framework for understanding consumers' reactions (Green, 
1999; Qualls \& Moore, 1990; Williams, Qualls \& Grier, 1995).

\section{In-group bias theory}

This theory suggests that individuals, as members of a social group, have a positive bias towards the other members of their group (Brewer, 1979). When a social interaction occurs, individuals produce comparisons and/or evaluations that enable them to judge their level of social distance and similarity from the contact. As a function of this social distance/similarity, the bias towards their own group will influence their social behaviour. Applied to advertising research, this theory implies that black consumers express more favourable responses towards advertisements featuring black models, similarly for white consumers towards advertisements featuring white models and so on (Green, 1999; Qualls \& Moore, 1990; Williams et al., 1995).

However, race is not the only relevant social identity for predicting advertising attitude (Williams, 1992). Even though race-based identification tends to overshadow both gender- and role-based identification (see Brumbaugh, 2009), Williams (1992) contends that, although a black viewer may respond more favourably to advertisements featuring black models (versus advertisements without black models), a black middle-class professional may also respond more favourably to advertisements with black middle-class professional models (versus advertisements featuring black models from other socioeconomic segments). However, little research has tested this assumption and evaluated the effect of consumers' multiple identities on advertising effectiveness.

In South Africa, little research has examined the impact of a model's race on advertising effectiveness. A literature search reveals only three advertising studies examining the South African context (Orpen, 1975; Grier \& Brumbaugh, 2007; Grier \& Deshpandé, 2001). Orpen (1975) shows that coloured viewers are not influenced by a model's racial group (coloured versus white), whereas Grier and colleagues (Grier \& Brumbaugh, 2007; Grier \& Deshpandé, 2001) find that black and coloured viewers (relative to white viewers) give higher ratings to advertising regardless of the model's race. However, none of these studies has taken into consideration the socioeconomic position occupied by the model in the advertisement. What is missing is an understanding of the effect of the depiction of a model beyond his/her perceived racial group. Understanding such effects is critical for South African advertisers in order to design adequate and successful cross-cultural advertising strategies.

\section{Problem statement}

Since the 1930s advertisers have recognised the economic potential of African/black consumers (Bryce, 1990). However, some advertisers were reluctant to target the black community, afraid of the white consumers' potential backlash, whereas others had reservations about the black consumers' financial muscle and their intellectual capacity to understand the advertising message (for an illustration of the debate see Society of Advertisers, 1958:4-16). As a result, there was limited focus on the black community by advertisers until the acknowledgment of the black consumer as a power in the late 1970s (Iheduru, 2004). This trend was given increased impetus by the demise of apartheid.

The demise of the apartheid regime engendered numerous changes in the South African advertising industry. While using multi-racial features has become a "social responsibility" (Johnson, 2009), the emergence of a growing black middle class as a financially viable target (Olivier, 2007) has encouraged advertisers to increasingly feature black models in their advertising strategy (Cassim \& Monteiro, 2001; Milner, 2007; North \& Millard, 2003). Advertisers assume that by featuring black models in their advertisements, black viewers will feel targeted and so will display positive attitude towards the advertisements and the brand due to an in-group bias. However, this may be an overly simplistic analysis of the situation in South Africa.

Indeed, although the end of the apartheid regime accelerated the emergence of a black middle class and, in so doing, diminished interracial inequality, it also increased intraracial inequality (Hamann, Agbazue, Kapelus \& Hein, 2005). Considering this growing inequality, the similarity perceived by the viewer with the model might not be simply a function of the perceived race of the model. Accordingly, and consistent with Williams' (1992) argument described earlier, viewers can perceive the model as similar in terms of race but also in terms of gender, marital status, and/or socioeconomic position. This possibility has been overlooked by extant advertising literature. This study examines which social identity (race versus socioeconomic position) is the more relevant/salient in South African consumers' identity to predict advertising effectiveness.

\section{Research objective}

This study examines if race, in comparison to another social identity (i.e. socioeconomic position), explains viewers' advertising responses. The first step of this study determines the effect of a model's social identity (i.e. racial group versus socioeconomic position) on advertising effectiveness. The second step considers whether this reaction is explained by viewers' felt targetedness, i.e. viewers' cognitive beliefs that the advertiser is attempting to reach them (Aaker, Brumbaugh \& Grier, 2000).

\section{The operationalisation of variables}

Three independent variables are considered in this study: models' racial group, model's socioeconomic position, and participants' racial group. The models' racial group was operationalised by two advertisements varying in their racial composition: an advertisement with a white model and another one with a black model. To operationalise models' socioeconomic position, both black and white models were represented either in a profession that matches the one of the participants' (i.e. lecturer) or not (i.e. worker). For the purpose of this study, the independent variable of race considers only black and white demographics. The first group refers to individuals whose ancestors inhabited South African soil before the European settlement, whereas the second group consists of people of European origin 
(Afolayan, 2004). However, it is acknowledged that race exists as a social construction with much meaning beyond the physical definition (Bhopal, 2004).

Two dependent variables were used, namely advertising effectiveness and felt targetedness. Advertising effectiveness is operationalised as advertising attitude, which is defined as "a predisposition to respond in a favourable or unfavourable manner to a particular advertising stimulus during a particular exposure occasion" (Lutz, 1985: 53). On the other hand, felt targetedness represents viewers' belief that they are the intended audience for the advertisement (Aaker et al., 2000). This belief has been found to be a key ad cognition variable in culturally-targeted advertising processing (Aaker et al., 2000).

\section{Research hypotheses}

The hypotheses tested in this study are:

$\mathrm{H}^{1}$ : Viewers' advertising attitude is influenced by both a model's racial group and profession. Black (white) viewers express higher advertising attitude when the model depicted in the advertisement is black (white), but only when this model has the same profession as them.

$\mathrm{H}^{2}$ : Both a model's racial group and profession influence viewers' belief that they are the intended audience for the advertisement. Black (white) viewers feel more targeted by an advertisement when the model depicted is black (white), but only when this model has the same profession as them.

$\mathrm{H}^{3}$ : The extent to which viewers believe that they are the intended audience for the advertisement influences their attitude towards the advertisement.

\section{Research design and methodology}

The design of the experiment involved a 2 (model's racial group: black versus white) $\times 2$ (model's profession: lecturer versus worker) $\times 2$ (respondent's racial group: black versus white) between subjects factorial design.

A sample of 147 male university lecturers (79 black and 68 whites) ranging from 24 to 72 years-old $\left(\mathrm{M}_{\text {black }}=41,10\right.$, $\left.\mathrm{SD}_{\text {black }}=9,48 ; \quad \mathrm{M}_{\text {white }}=42,79, \mathrm{SD}_{\text {white }}=11,70\right)$ was recruited. This sample was selected to control for socioeconomic position and other extraneous variables that could have influenced viewers' identity-based decision making (e.g. gender).

The stimuli consisted of four full-colour photographic advertisements for a fictitious brand. The product advertised was life insurance, as it does not possess any cultural stereotype and is not race-related. The advertisement was embedded in a press article about the National Arts Festival in order to make the experiment as realistic as possible and to reach a better external validity.

This study used digital techniques to control the vast majority of extraneous variables present in an advertisement. Firstly, it was decided that only male models should be used within the advertisements to match with our sample population and control for gender-based identity. Furthermore, the profession of the model in the advertisement was manipulated through the clothing and surroundings of the model. To represent the models with a profession similar to the demographic characteristics of the sample (i.e. lecturer), the models were depicted in an office, writing notes and with books in the background. On the other hand, the models with a profession different from the demographic characteristics of the sample (i.e. worker) were represented in a workshop wearing blue overalls. A pre-test sample evaluated correctly the profession of the models, i.e. lecturer versus worker. Moreover, another pre-test sample rated the photographs of the models separately to guarantee that models' attractiveness was similar across the manipulations. Similarly, the age of the four models was perceived as close (ranging from 45 to 47 years-old) and congruent with the sample.

The survey was initially presented as a research project about media. Participants completed the study individually. Participants were randomly assigned to one of the four advertisements (black lecturer, white lecturer, black worker, or white worker). After reading the article for about five minutes, participants were given the questionnaire booklet to complete. Advertising attitude was used to measure the effectiveness of the advertisement. Participants indicated their attitude toward the advertisement using two semantic differential scales anchored with unfavourable/favourable and boring/interesting (MacKenzie, Lutz \& Belch, 1986). The internal consistency reliability of this measure was respectable, with the scale attaining Nunnally's (1978) suggested Cronbach's alpha of 0,70 or higher $(\alpha=0,807)$. Participants indicated the extent to which they believed that the advertisement was intended for them (Aaker et al., 2000) with three items (i.e., I feel the advertisement was intended for people like me, I do not believe I was in the target market the company created the advertisement for [reverse coded], and the advertiser made that advertisement for people like me) which were averaged into a single measure of felt targetedness $(\alpha=0,736)$. Finally, respondents' racial group was measured by the emic self-report method of ethnic identification, i.e. participants ticked the racial group to which they belong, or wrote in one that was not listed (Grier \& Deshpandé, 2001).

\section{Empirical results}

The results of the experiment are presented and discussed according to the hypotheses presented earlier. Series of three-way analyses of variance (ANOVA) for the two first hypotheses are given below. Only significant main effects and interactions are mentioned in the results. The results for hypotheses $\mathrm{H}^{1}$ and $\mathrm{H}^{2}$ are presented in Table 1 .

\section{H1: Advertising attitude}

$\mathrm{H}^{1}$ proposes that both a model's racial group and profession influence viewers' advertising attitude. To test this hypothesis, a three-way ANOVA was conducted in which participants' racial group, model's racial group and model's profession were used as independent variables and attitude towards the advertisement as the dependant variable. Results reveal a main effect of the model's profession on advertising attitude, $\mathrm{F}(1,139)=13,305, \mathrm{p}<0,001$. Regardless of their 
race and of the model's race, viewers express more favourable advertising attitude when exposed to a lecturer $(\mathrm{M}=3,37)$ than to a worker $(\mathrm{M}=2,54)$. Unexpectedly, the two-way interaction between participants' racial group and the model's racial group is found not to influence viewers' advertising attitude, $\mathrm{F}(1,139)=2,292, \mathrm{p}>0,10$. Examination of the means shows that the race of a model does not have the same impact for black and white viewers. The results are depicted in Figure 1.

The results indicate that black viewers express higher advertising attitude when the model depicted in the advertisement is black $(\mathrm{M}=3,31)$ than white $(\mathrm{M}=2,60, \mathrm{p}<$ $0,05)$, whereas white viewers' attitude is not influenced by the race of the model $\left(\mathrm{M}_{\text {black }}=2,94 ; \mathrm{M}_{\text {white }}=2,91, \mathrm{p}>0,90\right)$. Furthermore, the three-way interaction between participants' racial group, model's racial group and model's profession is found not to be significant, $F(1,139)=0,716, p>0,30$. Consequently, the profession of the model does not moderate the influence of race on advertising attitude and $\mathrm{H}^{1}$ is rejected.
H2: Felt Targetedness

$\mathrm{H}^{2}$ assumes that both a model's racial group and profession influence viewers' felt targetedness. To test this hypothesis, a three-way ANOVA was conducted in which participants' racial group, model's racial group and model's profession were used as independent variables and felt targetedness as the dependant variable (see Table 1). Results reveal a significant main effect of the model's profession on felt targetedness, $\mathrm{F}(1,139)=31,091, \mathrm{p}<0,001$. Regardless of their race and of the model's race, viewers feel more targeted when exposed to a lecturer $(\mathrm{M}=3,79)$ than to a worker $(\mathrm{M}=2,58)$. A two-way interaction between participants' racial group and model's racial group is also found to influence viewers' felt targetedness, $F(1,139)=$ $31,201, \mathrm{p}<0,001$. The results are depicted in Figure 2.

Table 1: Hypotheses $\mathrm{H}^{\mathbf{1}}$ and $\mathrm{H}^{\mathbf{2}}$ - Three-way ANOVA

\begin{tabular}{|c|c|c|c|c|}
\hline & \multicolumn{4}{|c|}{ Dependent Variables } \\
\hline & \multicolumn{2}{|c|}{$\begin{array}{c}\mathbf{H}^{\mathbf{1}} \text { : Advertising } \\
\text { Attitude }\end{array}$} & \multicolumn{2}{|c|}{$\mathbf{H}^{2}$ : Felt Targetedness } \\
\hline & $\mathbf{F}$ & Sig, & $\mathbf{F}$ & Sig, \\
\hline Corrected Model & 2,880 & $0,008 *$ & 11,186 & $0,000^{*}$ \\
\hline Intercept & 719,691 & $0,000^{*}$ & 866,668 & $0,000 *$ \\
\hline Model's racial group & 2,257 & 0,135 & 0,026 & 0,871 \\
\hline Model's profession & 13,305 & $0,000 *$ & 31,091 & $0,000^{*}$ \\
\hline Respondent's racial group & 0,069 & 0,793 & 0,111 & 0,739 \\
\hline Model's racial group $\times$ Model's profession & 0,000 & 0,992 & 3,070 & 0,082 \\
\hline Model's race $\times$ Respondent's racial group & 2,292 & 0,132 & 31,201 & $0,000^{*}$ \\
\hline Model's profession $\times$ Respondent's racial group & 0,153 & 0,696 & 0,299 & 0,586 \\
\hline Model's racial group $\times$ Model's profession $\times$ Respondent's racial group & 0,716 & 0,399 & 11,412 & $0,001 *$ \\
\hline
\end{tabular}

\footnotetext{
$*=\mathrm{p}<0,05$
}

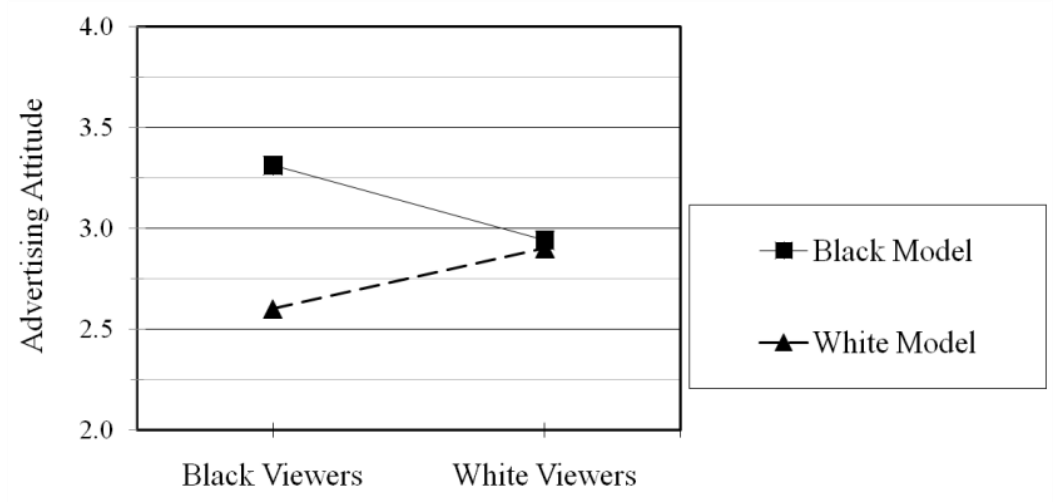

Figure 1: $\mathbf{H}^{1}$ - Two-way interaction viewers' racial group $\times$ Model's racial group on advertising attitude 
The results show that black viewers feel more targeted when the model depicted in the advertisement is black $(\mathrm{M}=3,86)$ than white $(M=2,55, \mathrm{p}<0,001)$. Similarly, white viewers feel more targeted when the model is white $(M=3,72)$ than black $(\mathrm{M}=2,57, \mathrm{p}<0,01)$. Finally, the three-way interaction between participants' racial group, model's racial group and model's profession is found to be significant, $\mathrm{F}(1,139)=11,412, \mathrm{p}<0,05$. The results are depicted in Figure 3.

The results indicate that white viewers feel significantly more targeted by the white model depicted as a lecturer (M $=4,85, \mathrm{p}<0,001)$ than by the white model depicted as a worker $(\mathrm{M}=2,65)$, whereas the representation of the black model does not influence white viewers' felt targetedness $\left(M_{\text {black worker }}=2,58, M_{\text {black lecturer }}=2,56, p>0,90\right)$. On the other hand, black viewers' felt targetedness is not influenced by the interaction between the model's racial group and the model's profession, $\mathrm{F}(1,75)=1,485, \mathrm{p}>0,231$. However, a closer examination of the means reveals that black viewers feel more targeted by the black lecturer $(\mathrm{M}=4,70)$ versus the black worker $(\mathrm{M}=3,02, \mathrm{p}<0,001)$, and feel more targeted by the white lecturer $(M=3,09)$ than by the white worker $(M=2,12, p<0,02)$. Hence, $\mathrm{H}^{2}$ is accepted.

H2: Regression linear felt targetedness on advertising attitude. The third and last hypothesis examines the influence of felt targetedness on advertising attitude. In other words, $\mathrm{H}^{3}$ assumes that the extent to which viewers feel targeted by an advertisement influences viewers' advertising attitude. A regression analysis, presented in Table 2, tests this hypothesis.

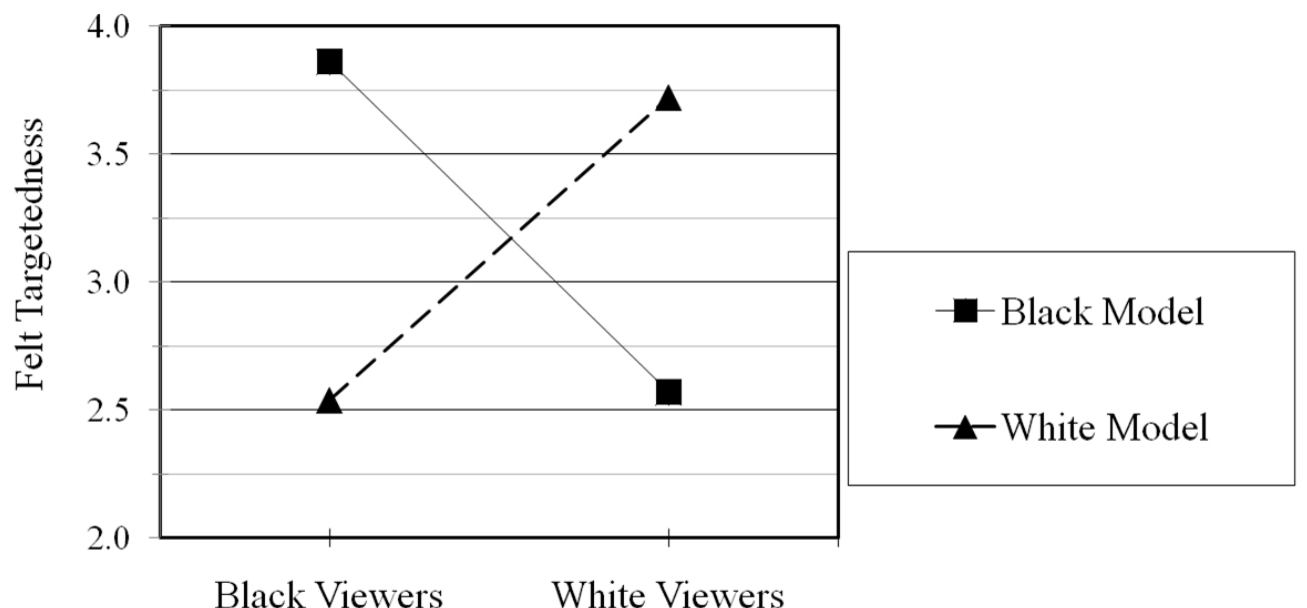

Figure 2: $\mathbf{H}^{2}-$ Two-way interaction viewers' racial group $\times$ Model' racial group on felt targetedness
Black viewers
White viewers

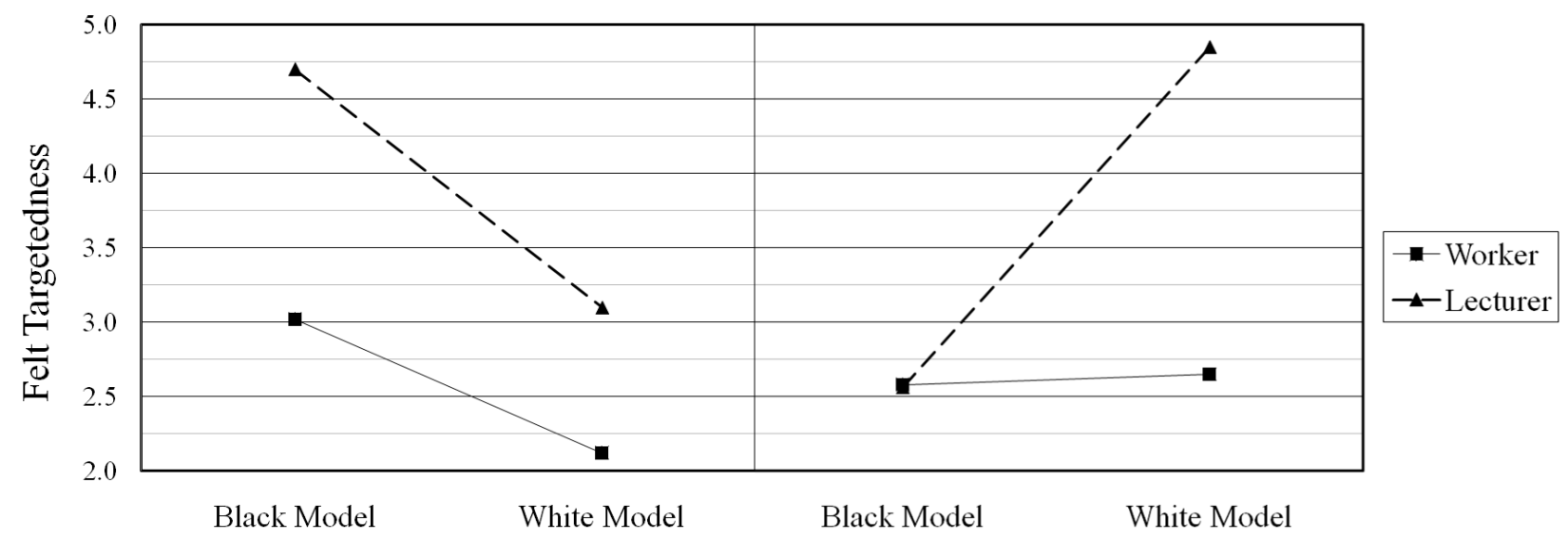

Figure 3: $\mathbf{H}^{2}-$ Three-way interaction viewers' racial group $\times$ Model's racial group $\times$ Model's profession on felt targetedness

Table 2: Hypothesis $\mathbf{H}^{3}$ - Linear regression

\begin{tabular}{c|c|c|c|c|c|c}
\hline \multirow{2}{*}{$\begin{array}{l}\text { Dependent variable: } \\
\text { Advertising Attitude }\end{array}$} & \multicolumn{7}{|c}{ Linear regression } \\
\cline { 2 - 8 } & $\mathbf{F}$ & Df & Sig. & Std. $\boldsymbol{\beta}$ & $\mathbf{R}^{\prime}$ & $\mathbf{R}^{\mathbf{2}}$ \\
\hline Felt Targetedness & 32,437 & 1,145 & $0,000^{*}$ & 0,428 & 0,428 & 0,183 \\
\hline
\end{tabular}

$*=\mathrm{p}<0,05$ 
The result of the linear regression shows a significant relationship between the felt targetedness on advertising attitude (Std. $\beta=0,428, p=0,000)$ and $\mathrm{H}^{3}$ is accepted.

\section{Conclusion}

The results of this study provide some important insights in the field of targeted advertising in South Africa. Results indicate that both black and white viewers express higher advertising attitude when the model is depicted as a lecturer regardless of his racial group. Such findings highlight the role of socioeconomic position on advertising effectiveness as viewers have a more favourable attitude when exposed to a model that has the same position as them. Typically, while the results are consistent with previous US studies that shows that the racial group of the model matters for social minority viewers only (i.e. black viewers, see Aaker et al., 2000), findings show that a "perfect" interaction between consumers' multiple identities is not necessary to influence advertising effectiveness. Simply put, the model does not need to be similar in terms of both race AND profession to influence advertising effectiveness. In this study, being depicted as a lecturer is enough to produce persuasion amongst black and white lecturers.

Furthermore, despite the strong relationship between felt targetedness and advertising attitude $\left(\right.$ see $\mathrm{H}^{3}$ ), the results associated with $\mathrm{H}^{2}$ suggest that both constructs may work differently. In particular, findings indicate that although viewers correctly perceive that advertisers aim to target them based on both their race AND profession (see Figure 3 ), their final advertising response is determined mostly by the socioeconomic position of the model.

\section{Limitations of the study}

The main limitation of this study concerns sampling from a university male lecturer population. Although this restricted choice aimed to control for profession and gender, further research needs to investigate a larger sample (the study may have failed to find statistically significant results because of the small sample size), broader demographic groups (amongst both respondents and models) as well as additional social identities besides race and profession. Specifically, advertising responses from a sample of "workers" may be compared to the present results. In the same vein, more professions within the "same" socio-economic position may be investigated. Moreover, recruiting respondents at universities may have primed respondents as it makes their profession a more salient self-identity than it would otherwise be. Future research may examine more neutral environments. Further research can also include consumers' responses to a broader panel of products from fictitious and real brands.

\section{Managerial implications}

The managerial implications resulting from this study are rich for South African advertisers. This study confirms that using black models has a positive effect on black consumers' persuasion. However, the findings also suggest that a model's socioeconomic position may have a greater impact than race on predicting advertising effectiveness across viewers. As a result, advertisers should not merely take into consideration the racial composition of their target market but should also consider other social identities as critical. Thus, advertisers need to understand the entire range of social categories their target market belongs to, identify the more salient/relevant identity in function of the context and target accordingly and respectfully. Only then will advertisers be able to implement successful crosscultural marketing strategy in post-apartheid South Africa.

\section{References}

Aaker, J.L., Brumbaugh, A.M. \& Grier, S.A. 2000. 'Nontarget markets and viewer distinctiveness: The impact of target marketing on advertising attitudes', Journal of Consumer Psychology, 9(3): 127-140.

Afolayan, F. 2004. Culture and customs of South Africa. Wesport: Greenwood Press.

Barban, A.M. \& Cundiff, E.W. 1964. 'Negro and white response to advertising stimuli', Journal of Marketing Research, 1(4): 53-56.

Bhopal, R. 2004. 'Glossary of terms relating to ethnicity and race: for reflection and debate', Journal of Epidemiology \& Community Health, 58(5): 441-445.

Brewer, M. 1979. 'In-group bias and the minimal intergroup situation: A cognitive-motivational analysis', Psychological Bulletin, 86: 307-324.

Brumbaugh, A.M. 2009. 'Why do I identify with thee? Let me count three ways: How ad context influences race-based character identification', Psychology \& Marketing, 26(11): 970-986.

Bryce, A. 1990. A pictorial history of advertising in South Africa. Cape Town: Don Nelson.

Cagley, J.W. \& Cardozo, R.N. 1970. 'White response to integrated advertising', Journal of Advertising Research, 10(April): 35-39.

Cassim, S. \& Monteiro, M. 2001. 'Black role portrayals in South African television advertising'. Ecquid Novi, 22(1): 106-123.

Choudhury, P.K. \& Schmid, L.S. 1974. 'Black models in advertising to blacks', Journal of Advertising Research, 14(June): 19-22.

Cui, G. 2001. 'Marketing to ethnic minority consumers: A historical journey (1932-1997)', Journal of Macromarketing, 21(1): 23-31.

Green, C.L. 1999. 'Ethnic evaluations of advertising: Interaction effects of strength of ethnic identification, media placement, and degree of racial composition', Journal of Advertising, 28(1): 49-64.

Grier, S.A. \& Brumbaugh, A.M. 2007. 'Compared to whom? The impact of status on third person effects in 
advertising persuasion in a South African context', Journal of Consumer Behaviour, 6(Jan.-Feb.): 5-18.

Grier, S.A. \& Deshpandé, R. 2001. 'Social dimensions of consumer distinctiveness: Influence of social status on group identity and advertising persuasion', Journal of Marketing Research, 38(2): 216-224.

Hamann, R., Agbazue, T., Kapelus P. \& Hein, A. 2005. 'Universalizing corporate social responsibility? South African challenges to the international organization for standardization's new social responsibility standard', Business and Society Review, 110(1): 1-19.

Iheduru, O.C. 2004. 'Black economic power and nationbuilding in post-apartheid South Africa', Journal of Modern African Studies, 42(1): 1-30.

Johnson, G.D. 2009. 'The social dimension of multi-racial advertising: Its impact on consumers' attitude', South African Journal of Business Management, 40(2): 45-52.

Lutz, R.J. 1985. 'Affective and cognitive antecedents of attitude toward the ad: A conceptual framework'. In Alwitt, L. \& Mitchell, A. (Eds.). Psychological processes and advertising effects. Hillsdale, NJ: Lawrence Erlbaum Associates.

MacKenzie, S.B., Lutz, R.J. \& Belch, G.E. 1986. 'The role of attitude toward the ad as a mediator of advertising effectiveness: A test of competing explanations', Journal of Marketing Research, 23: 130-143.

Milner, L.M. 2007. 'Race portrayals in Ghana, Kenya, and South Africa television advertisements', Journal of African Business, 8(2): 41-59.

North, E. \& Millard, S. 2003. 'Children and race in South African magazine advertising: Pre- and post-apartheid', Ecquid Novi, 24(1): 37-54.

Nunnally, J. 1978 Psychometric theory. New York: McGraw-Hill.

Olivier, D. 2007. 'South Africa poised to become a loyalty marketing gem,' Journal of Consumer Marketing, 24(3): 180-181.

Orpen, C. 1975. 'Reactions to black and white models', Journal of Advertising Research, 15(5): 75-79.

Qualls, W.J. \& Moore, D.J. 1990. 'Stereotyping effects on consumers' evaluation of advertising: impact of racial differences between actors and viewers', Psychology \& Marketing, 7(2): 135-151.

Schlinger, M.J. \& Plummer, J.T. 1972. 'Advertising in black and white', Journal of Marketing Research, 9(May): 149153.

Society of Advertisers. 1958. Report of the first advertising convention in South Africa. Johannesburg: Statistic Holding.
Solomon, P.J., Bush, R.F. \& Hair Jr., J.F. 1976. 'White and black consumer sales response to black models', Journal of Marketing Research, 13: 431-434.

Stafford, J.E., Birdwell, A.E. \& Van Tassel, C.E. 1970. 'Integrated advertising - White backlash?', Journal of Advertising Research, 10(2): 15-20.

Whittler, T.E. 1989. 'Viewers' processing of actor's race and message claims in advertising stimuli', Psychology and Marketing, 6(4): 287-309.

Whittler, T.E. 1991. 'The effects of actors' race in commercial advertising: Review and extension', Journal of Advertising, 20(1): 54-60.

Williams, J.D. 1992. 'Reflections of a black middle-class: Caught between two worlds or getting the best of both?' In Sherry, J. \& Sternthal, B. (Eds.). Advances in Consumer Research, 19. Provo; UT: Association for Consumer Research.

Williams, J.D., Qualls, W.J. \& Grier, S.A. 1995. 'Racially exclusive real estate advertising: Public policy implications for fair housing practices', Journal of Public Policy and Marketing, 14: 225-244. 